\title{
Evaluation of hand-foot syndrome and hand-foot skin reaction: Case series
}

\section{El-ayak sendromu ve el-ayak deri reaksiyonunun olgu serisi ile değerlendirilmesi}

\section{Hatice Gamze Demirdağ, ๑ Burcu Tuğrul Ayanoğlu, ๑ Bașak Yalıcı Armağan}

Ankara Dr. Abdurrahman Yurtaslan Oncology Training and Research Hospital, Clinic of Dermatology, Ankara, Turkey

\begin{abstract}
Hand-foot syndrome (palmoplantar erythrodysesthesia, palmar-plantar erythema, toxic erythema of the palms and soles, or Burgdorf's syndrome) is characterized by painful predominantly palmoplantar lesions with the association of different chemotherapeutic agents. More recently, hand-foot skin reaction has been reported to be associated with regimens using targeted agents, in particular the multikinase inhibitors. Hand-foot syndrome/skin reaction has a major impact on patient's quality of life, necessitating dose reduction or treatment interruption. In this article, hand-foot syndrome and hand-foot skin reaction were discussed through patients consulted our dermatology outpatient clinic Keywords: Hand-foot syndrome, hand-foot skin reaction, chemotherapy, multikinase inhibitors
\end{abstract}

Öz

El-ayak sendromu (palmoplantar eritrodizestezi, palmar-plantar eritem, avuç içi ve ayak tabanlarının toksik eritemi veya Burgdorf sendromu) başıca palmoplantar bölgede ağrılı lezyonlarla seyreden, farklı kemoterapötik ajanlarla ilişkisi saptanmış bir deri reaksiyonudur. Son zamanlarda hedefe yönelik tedavilerin özellikle çoklu kinaz inhibitörlerinin kullanımı ile el-ayak deri reaksiyonu olarak adlandırılan yeni bir antite bildirilmiştir. El-ayak sendromu/deri reaksiyonunun, tedavi dozlarının kesilmesine veya azaltılmasına neden olarak hastaların yaşam kalitesi üzerine önemli etkileri bulunmaktadır. Burada deri ve zührevi hastalıklar polikliniğimize konsülte edilen olgular üzerinden el-ayak sendromu ve deri reaksiyonu tartışlacaktır.

Anahtar Kelimeler: El-ayak sendromu, el-ayak deri reaksiyonu, kemoterapi, çoklu kinaz inhibitörleri

\section{Introduction}

Hand-foot syndrome, also called palmoplantar erythrodysesthesia, palmar-plantar erythema, Burgdorf syndrome, or toxic erythema of palms and soles is a common skin reaction which develops due to chemotherapeutic agents $^{1}$. The most common causative agents are doxorubicin, liposomal doxorubicin, docetaxel, 5-fluorouracil (5-FU), cytarabine, and capecitabine, while the syndrome can also be seen with the use of paclitaxel, hydroxyurea, methotrexate, 6-mercaptopurine, cyclophosphamide, cisplatin, daunorubicin, etoposide, vinorelbine, irinotecan, and epirubicin ${ }^{2}$. Recently, after the introduction of multikinase inhibitors in oncology, palmoplantar reactions that show specific clinical findings have been recorded and characterized as hand-foot skin reaction. The main causative drugs for this reaction are multikinase inhibitors, such as sorafenib, sunitinib, pazopanib, axitinib and regorafenib, and BRAF inhibitors such as vemurafenib and dabrafenib ${ }^{1-3}$. Here, hand-foot skin syndrome and hand-foot skin reaction are discussed based on the cases consulted physicians of the dermatology outpatient clinic.

\section{Method and Results}

Patients, who were receiving chemotherapy and had complaints of hand and/or foot reactions and were referred to the dermatology outpatient clinic between January 2016

Address for Correspondence/Yazışma Adresi: Hatice Gamze Demirdağ MD, Ankara Dr. Abdurrahman Yurtaslan Oncology Training and Research Hospital, Clinic of Dermatology, Ankara, Turkey Phone: +90 3123360909 E-posta: demirdaggamze@gmail.com Received/Geliş Tarihi: 26.03.2018 Accepted/Kabul Tarihi: 09.10.2018 ORCID ID: orcid.org/0000-0001-9484-2054

(C) Copyright 2019 by Turkish Society of Dermatology and Venereology

Turkderm-Turkish Archives of Dermatology and Venereology published by Galenos Yayınevi. 
and June 2017, were clinically evaluated. Gender, age, type of cancer, the chemotherapeutic agent that the patient was receiving, the day, week or cycle of chemotherapy at the time of presentation and the grade of hand-foot syndrome/reaction were recorded. The informed consent forms of patients were obtained.

A total of 28 patients with a mean age of 60.9 years (36-81) were included. Seventeen (62.5\%) patients were female and 11 (37.5\%) were male. Almost half of the patients had breast cancer among the other types of cancer. The chemotherapeutics administered were as follows: paclitaxel in 5 patients, docetaxel in 5 , capecitabine in 5 , cetuximab in 4, capecitabine + lapatinib in 2, capecitabine + cetuximab in 1, capecitabine + paclitaxel in 1, sorafenib in 2, pazopanib in 1, panitumumab in 1, and clofarabine + cytosine arabinoside in 1 patient. Ten patients (35.7\%) had grade 1, 12 patients (42.9\%) had grade 2 and 6 patients (21.4\%) had grade 3 hand-foot syndrome/skin reaction (Table 1).

\section{Discussion}

A clinical entity named hand-foot skin reaction has emerged with the use of new targeted agents in cancer treatment. Its difference from the classical hand-foot syndrome has been established in terms of onset of the symptoms, clinical findings, location, and pathogenesis. In handfoot syndrome, the palms, soles, dorsal surface of the hands, feet and the areas of occlusion, friction and pressure are affected. Symmetrical erythema and edema are seen in the palm and sole with accompanying neuropathic pain. It may progress to blistering with desquamation, erosion, and ulceration. Palms are involved more frequently compared to the soles. Histopathology reveals basal layer vacuolar degeneration or full-thickness necrosis, spongiosis, hyperkeratosis, and parakeratosis. Sweat gland-related toxicity may play a role in the pathogenesis. On the other hand, hand-foot skin reaction affects flexural and pressurebearing areas, including fingertips, interdigital web spaces, heels, lateral aspect of the feet, and the joints. Soles are involved more frequently compared to palms. Localized tender lesions are seen on

\section{Table 1. The clinicial features of patients with hand-foot syndrome/skin reaction}

\begin{tabular}{|c|c|c|c|c|c|c|}
\hline No & Gender & Age & Type of cancer & Chemotherapeutic & Cycle & Grade \\
\hline 1 & $\mathrm{~F}$ & 60 & Metastatic breast cancer & Capecitabine & 52. cure & 2 \\
\hline 2 & M & 60 & Metastatic colon cancer & Setuksimab & 7. cure & 1 \\
\hline 3 & $\mathrm{~F}$ & 61 & Metastatic tiroid cancer & Sorafenib & 10. day & 2 \\
\hline 4 & $\mathrm{~F}$ & 42 & Breast cancer & Paclitaxel & 10. week & 1 \\
\hline 5 & M & 67 & Metastatic colon cancer & Panitumumab & 1. cure & 3 \\
\hline 6 & M & 75 & Metastatic prostate cancer & Docetaxel & 3. cure & 2 \\
\hline 7 & $\mathrm{~F}$ & 65 & Metastatic breast cancer & Capecitabine & 2. cure & 3 \\
\hline 8 & $\mathrm{~F}$ & 47 & Metastatic breast cancer & Capecitabine + Lapatinib & 5. cure & 3 \\
\hline 9 & M & 62 & Metastatic colon cancer & Capecitabine + Setuksimab & 5. cure & 2 \\
\hline 10 & $\mathrm{~F}$ & 60 & Metastatic breast cancer & Paclitaxel & 16. week & 2 \\
\hline 11 & M & 59 & Metastatic colon cancer & Setuksimab & 5. cure & 3 \\
\hline 12 & $\mathrm{~F}$ & 58 & Metastatic breast cancer & Paclitaxel & 12. week & 1 \\
\hline 13 & M & 61 & Metastatic rectum cancer & Setuksimab & 3. cure & 2 \\
\hline 14 & $\mathrm{~F}$ & 66 & Metastatic breast cancer & Capecitabine + Lapatinib & 42. cure & 2 \\
\hline 15 & $\mathrm{~F}$ & 56 & Breast cancer & Docetaxel & 1. cure & 1 \\
\hline 16 & $\mathrm{~F}$ & 36 & AML & Klofarabin + ARA-C & 7. day & 2 \\
\hline 17 & M & 62 & Metastatic prostate cancer & Docetaxel & 3. cure & 1 \\
\hline 18 & $\mathrm{~F}$ & 60 & Breast cancer & Docetaxel & 1. cure & 2 \\
\hline 19 & $\mathrm{~F}$ & 66 & Breast cancer & Paclitaxel & 7. cure & 1 \\
\hline 20 & $\mathrm{~F}$ & 66 & Metastatic breast cancer & Capecitabine + Paclitaxel & 3. cure & 1 \\
\hline 21 & $\mathrm{~F}$ & 50 & Metastatic tiroid cancer & Sorafenib & 2 year & 3 \\
\hline 22 & $\mathrm{~F}$ & 76 & Breast cancer & Paclitaxel & 12. week & 2 \\
\hline 23 & M & 60 & Metastatic renal cancer & Pazopanib & 1. month & 2 \\
\hline 24 & M & 63 & Metastatic rectum cancer & Setuksimab & 1. week & 3 \\
\hline 25 & M & 60 & Rectum cancer & Capecitabine & 25. day & 1 \\
\hline 26 & M & 61 & Metastatic prostate cancer & Docetaxel & 6. cure & 1 \\
\hline 27 & $\mathrm{~F}$ & 81 & Metastatic breast cancer & Capecitabine & 25. cure & 2 \\
\hline 28 & $\mathrm{~F}$ & 67 & Colon cancer & Capecitabine & 5. cure & 1 \\
\hline
\end{tabular}

F: Female, M: Male, AML: Acute myelocytic leukemia, ARA-C: Cytosine arabinoside 
the areas exposed to friction and trauma. Lesions may appear as blisters or focal hyperkeratosis overlying an erythematous base. Welldemarcated dyskeratotic, discohesive keratinocytes are observed in histopathology. Vascular mechanisms are found to be responsible for pathogenesis ${ }^{2,3}$.

Hand-foot syndrome is evaluated in 3 grades according to the National Cancer Institute criteria. Painless minimal skin changes (erythema, edema or hyperkeratosis) are seen in grade 1, while skin lesions (peeling, blister, bleeding, edema or hyperkeratosis) or pain are observed in grade 2. Painful and severe skin changes in addition to limited self-care activities are seen in grade $3^{4}$. The grades of the hand-foot syndrome/ skin reaction in our patients are shown in Figures 1, 2 and 3.

Patients should be informed of the possibility of having hand-foot syndrome/skin reaction prior to the initiation of chemotherapy. Patients should refrain from mechanical trauma to the skin such as pressure, friction, and heat. Regular use of moisturizers is recommended. Thick cotton gloves and socks can be used to protect palms and soles from damage and to keep them dry ${ }^{5}$. In the treatment of grade 1 , moisturizing creams, keratolytic creams, and cushioning of the affected regions with gel or foam-based shock absorber soles and soft shoes are recommended. Treatment is maintained at the same dosage. In the treatment of grade 2, potent topical corticosteroids are applied for seven to ten days additionally. A dose reduction of $50 \%$ should be considered. Local antiseptic bath is used for the blisters and erosions in stage 3 , in addition to the treatments used in stage 1 and 2 . Treatment is interrupted at least for one week and started in a decreased dose after improvement of the condition to a level of grade 0 or grade 1 disease ${ }^{6}$. Among the patients in this case series, 10, 12 and 6 patients were found to have grade 1, grade 2 and grade 3 disease, respectively. The treatment was discontinued until the symptoms subsided in patients with grade 3 . The incidence of hand-foot syndrome varies according to the causative drug. Capecitabine was the most frequently used chemotherapeutic drug in this case series. Capecitabine is an oral precursor of 5-FU. Approximately 54\% of patients receiving this treatment may have hand-foot syndrome. This effect may be seen during each cycle or each dose of treatment applied. Dose reduction or interruption might be needed in about $15-25 \%$ of patients ${ }^{7}$. Another commonly used drug group in the cases presented here was taxane. Taxane is a group of chemotherapeutic drugs which exerts its activity by mitotic inhibition. Docetaxel and paclitaxel rank at the top of the agents in this group that can cause hand-foot syndrome ${ }^{8}$. The incidence of the syndrome has been reported to be $6-58 \%$ with docetaxel treatment ${ }^{3}$.

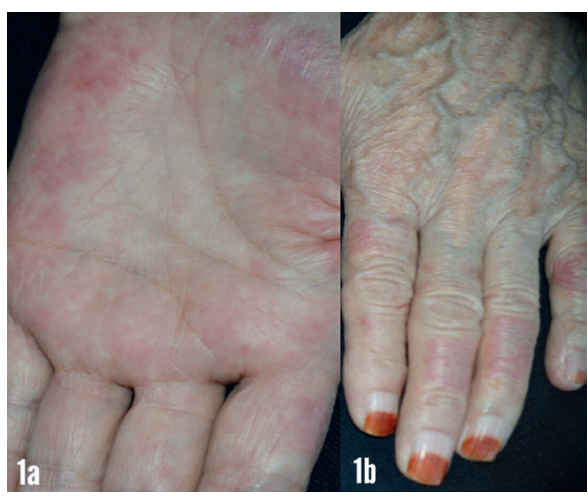

Figure 1. $a, b)$ Erythema of the palms and dorsal hands in a female patient receiving paclitaxel (grade 1)
The severity of the syndrome caused by docetaxel, in general, is higher compared to paclitaxel, although cases of severe hand-foot syndrome induced by paclitaxel have been reported ${ }^{8}$. Combination treatment was also encountered among the cases presented here. The most frequent dermatological side effect associated with generally well-tolerated capecitabine and paclitaxel combination is hand-foot syndrome, due to long-term usage of cytostatic agents. The incidence of hand-foot syndrome was found to be $42 \%$ with mild to moderate severity in a study performed in patients receiving this treatment ${ }^{9}$. This rate was reported to increase up to $56-63 \%$ with the combination of another taxane, docetaxel plus capecitabine ${ }^{2}$.

Multikinase inhibitors generally cause hand-foot skin reaction. In a study, the incidence was reported to be $12 \%$ in patients on sunitinib, pazopanib, axitinib and sorafenib (tyrosine kinase inhibitors) of whom $58 \%$ required no treatment, while 34\% needed pharmacological treatment, 4\% non-pharmacological treatment and $4 \%$ required

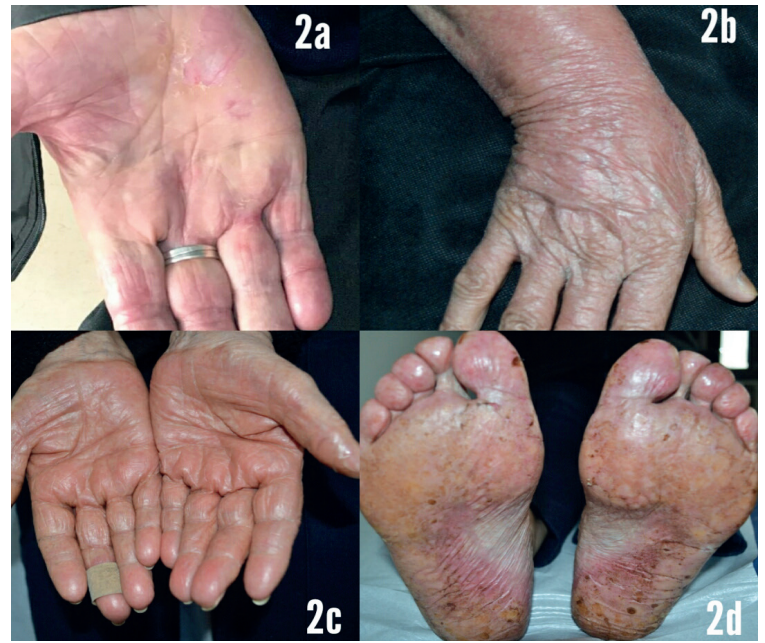

Figure 2. a) Erythema and desquamation in male patient receving pazopanib (grade 2), b) painful erythema in a female patient on paclitaxel therapy (grade 2), c) erythema of the palms in a female patient on capecitabine therapy (grade 2), d) difuse erythema, mild desquamation and crusted lesions in a patient receiving capecitabine (grade 2)

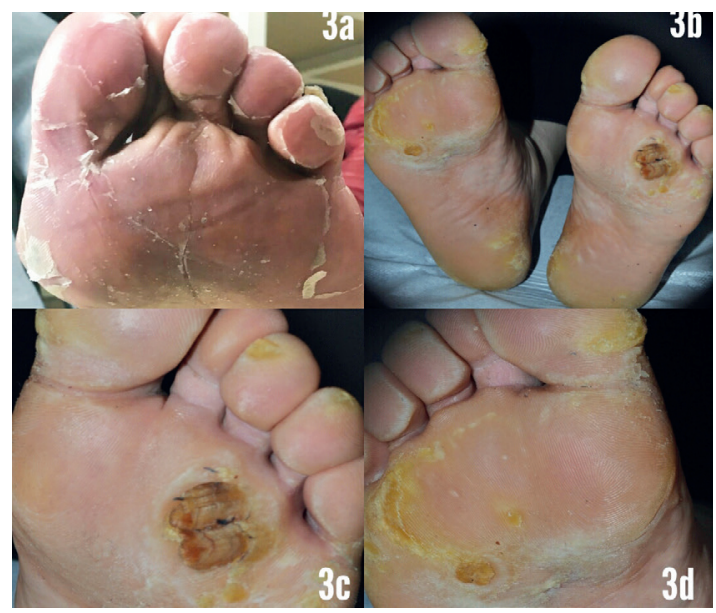

Figure 3. a) Diffuse painful erythema and desquamation in male patient on cetuximab therapy (grade 3), b-d) bilateral focal callus-like hyperkeratosis of the soles in a female patient receiving sorafenib therapy (Hand-foot skin reaction grade 3) 
both $^{10}$. In another study, hand-foot skin reaction was reported in $10-28 \%$ and $10-62 \%$ of patients receiving sorafenib and sunitinib treatments, respectively ${ }^{3}$. Pazopanib, an orally administered multitargeted tyrosine kinase inhibitor, predominantly inhibits vascular endothelial growth factor receptor-1, 2 and 3, platelet-derived growth factor receptor- $\alpha$ and $-\beta$, and the stem cell factor receptor $c-K i t$. It is approved for the treatment of advanced renal cell carcinoma. The incidence of associated hand-foot skin reaction has been reported to be $6 \%$. The rate of this adverse effect was observed to be lesser compared to that in patients receiving sunitinib ${ }^{11}$. On the other hand, lapatinib is the first dual-acting tyrosine kinase inhibitor which inhibits both human epidermal growth factor receptor type 2 (HER2/neu) and epidermal growth factor receptor. The most frequent adverse effect in patients with metastatic breast cancer receiving lapatinib and capecitabine combination treatment has been reported to be hand-foot syndrome with an incidence of $46.8 \%{ }^{12}$.

Cetuximab and panitumumab which are monoclonal antibodies inhibiting epidermal growth factor receptor are also used in the treatment of various cancer types. The incidence of skin toxicity has been reported to be $50-90 \%$ in patients receiving epidermal growth factor inhibitors. Papulopustular rash is the most frequent adverse effect. The second most common adverse effects are atrophic, sensitized skin, dryness and painful fissures in the palms and soles ${ }^{13}$.

Acral erythema has been reported in patients with acute myelocytic leukemia receiving high-dose chemotherapy. Cytosine arabinoside treatment is among the most frequent causes of erythema ${ }^{14}$. One patient was found to receive this treatment in the case series presented here.

The risk of developing hand-foot syndrome depends both on the dose and drug $^{1,3}$. Dosage and female gender have been defined as risk factors in the development of this syndrome, while risk factors of handfoot skin reaction caused by multikinase inhibitors have been reported to be tumor type, normal pretreatment white blood cell count, female gender, good performance status, liver metastases, and the number of affected organs ${ }^{3}$. The onset of hand-foot skin reaction is usually within two to four weeks, however, it may occur in the first one-three months of the treatment. On the other hand, symptoms of the hand-foot syndrome may occur in 1-21 days after high-dose pulse treatment and in months in low-dose continuous treatment ${ }^{2}$. In the series presented here, we noticed that symptoms might be seen in different treatment periods and cycles in each patient and more than one syndrome were seen in one patient during the chemotherapy period. Individual genetic changes play a major role in the risk of development of this syndrome. Studies on genetic variations have recently been published in the literature. In their study, Mattison et al..$^{15}$ have reported that dihydropyrimidine dehydrogenase enzyme deficiency was seen to underlie the genetic tendency to capecitabine-induced toxicities and this deficiency affected Afro-Americans more frequently. It may explain the ethnic variations in hand-foot syndrome susceptibility. Also, in another study, the loss of rs3215400 allele in the cytidine deaminase gene was found to increase capecitabine-induced hand-foot syndrome risk ${ }^{16}$. Hand-foot syndrome and skin reaction can severely affect the physical, psychological and social lives of the patients. It may limit the antitumoral effect by causing dose reduction and cessation of the chemotherapy, although it has no direct effect on survival ${ }^{5}$. Patients should be informed about the development of this syndrome and recommendations prior to starting the drugs that can cause hand-foot syndrome/skin reaction. Early diagnosis and appropriate dermatological treatment are suggested to be important since the treatment is based on clinical appearance.

\section{Ethics}

Informed Consent: The informed consent forms of patients were obtained.

Peer-review: Externally peer-reviewed.

\section{Authorship Contributions}

Surgical and Medical Practices: H.G.D., B.T.A., B.Y.A., Concept: H.G.D., Design: H.G.D., B.T.A., B.Y.A., Data Collection or Processing: H.G.D., B.T.A., B.Y.A., Analysis or Interpretation: H.G.D., B.T.A., B.Y.A., Literature Search: H.G.D., Writing: H.G.D.

Conflict of Interest: No conflict of interest was declared by the authors.

Financial Disclosure: The authors declared that this study received no financial support.

\section{References}

1. Nikolaou V, Syrigos K, Saif MW. Incidence and implications of chemotherapy related hand-foot syndrome. Expert Opin Drug Saf 2016;15:1625-33.

2. Degen A, Alter M, Schenck F, et al. The hand-foot-syndrome associated with medical tumor therapy-classification and management. J Dtsch Dermatol Ges 2010;8:652-61.

3. Miller KK, Gorcey L, McLellan BN. Chemotherapy-induced hand-foot syndrome and nail changes: a review of clinical presentation, etiology, pathogenesis, and management. J Am Acad Dermatol 2014;71:787-94.

4. National Cancer Institute. Common terminology criteria for adverse events (CTCAE) v4.03. NCI, NIH, DHHS. June 14, 2010. NIH publication.

5. Lacouture ME, Wu S, Robert C, et al. Evolving strategies for the management of hand-foot skin reaction associated with the multitargeted kinase inhibitors sorafenib and sunitinib. Oncologist 2008;13:1001-11.

6. Robert C, Sibaud $V$, Mateus $C$, et al. Advances in the management of cutaneous toxicities of targeted therapies. Semin Oncol 2012;39:227-40.

7. Leicher LW, de Graaf JC, Coers W, et al. Tolerability of Capecitabine Monotherapy in Metastatic Colorectal Cancer: A Real-World Study. Drugs R D 2017;17:117-24.

8. Assi HA, Ayoub ZA, Jaber SM, et al. Management of paclitaxel-induced hand-foot syndrome. Breast Care (Basel) 2013;8:215-7.

9. Batista N, Perez-Manga G, Constenla M, et al. Phase II study of capecitabine in combination with paclitaxel in patients with anthracycline-pretreated advanced/metastatic breast cancer. Br J Cancer 2004;90:1740-6.

10. Srinivas $S$, Stein $D$, Teltsch DY, et al. Real-world chart review study of adverse events management in patients taking tyrosine kinase inhibitors to treat metastatic renal cell carcinoma. J Oncol Pharm Pract 2017:1078155217719583.

11. Frampton JE. Pazopanib: a Review in Advanced Renal Cell Carcinoma. Target Oncol 2017;12:543-54.

12. Cetin B, Benekli M, Turker I, et al. Lapatinib plus capecitabine for HER2positive advanced breast cancer: a multicentre study of Anatolian Society of Medical Oncology (ASMO). J Chemother 2014;26:300-5.

13. Belloni $B$, Schönewolf $N$, Rozati $S$, et al. Cutaneous drug eruptions associated with the use of new oncological drugs. Chem Immunol Allergy 2012;97:191-202

14. Demirçay Z, Gürbüz O, Alpdoğan TB, et al. Chemotherapy-induced acral erythema in leukemic patients: a report of 15 cases. Int J Dermatol 1997;36:593-8.

15. Mattison LK, Fourie J, Desmond RA, et al. Increased prevalence of dihydropyrimidine dehydrogenase deficiency in African-Americans compared with Caucasians. Clin Cancer Res 2006;12:5491-5.

16. Caronia D, Martin M, Sastre J, et al. A polymorphism in the cytidine deaminase promoter predicts severe capecitabine-induced hand-foot syndrome. Clin Cancer Res 2011;17:2006-13. 